\title{
Assessment of Solar Energy Source Distribution and Potential in Zambia
}

\author{
Mabvuto MWANZA ${ }^{1}$, Jamel CHACHAK ${ }^{1}$, Numan S. ÇETIN ${ }^{1}$, Koray ÜLGEN ${ }^{1}$ \\ ${ }^{1}$ Solar Energy Institute, Ege University
}

\begin{tabular}{l} 
Article Info \\
\hline Article history: \\
Received Jan $03^{\text {rd }}, 2017$ \\
Revised Apr $04^{\text {th }}, 2017$ \\
Accepted June $16^{\text {th }}, 2017$ \\
\hline
\end{tabular}

Keyword:

Solar energy potential

Zambia

Solar Radiation

Renewable energy technology

Photovoltaic

\begin{abstract}
Zambia is vastly endowed with a wide range of energy resources. Yet, to date, Zambia has not fully exploited its potential in solar energy utilisation for electricity generation due to various reasons such as lack of understanding of the distribution of solar energy potential in the country and limitation of access to solar energy resource information. This paper assesses the solar energy distribution and potential in Zambia. Nine provinces with different geographical and climatic regions that makes up Zambia were assesed. The distribution of solar radiation within the country were assessed using spatial analysis in ArcGIS Software. The 22year period solar datasets were considered for assessment. These datasets were obtained from NASA Atmospheric Science Data Center using Surface Meteorology and Solar Energy. The analyzed results indicate that Zambia has approximately 20,442TWh/year technical solar energy potential and receives $2109.97 \mathrm{kWh} / \mathrm{m} 2$ of solar energy per year with 4403.12 hours of sunshine. The country has $186,121 \mathrm{~km} 2$ available and suitable land area for RETs implementations. This study is important as it present an overview of the technical solar energy potential for Zambia which is vital for decision making, energy mix and sustainable deployment of solar energy technologies in the country.
\end{abstract}

\section{Corresponding Author:}

Mabvuto MWANZA,

Solar Energy Institute,

Ege University,

35100 Bornova, Izmir, Turkey.

Email: mabvuto mwanza@yahoo.com

\section{Introduction}

Energy is one of the basic necessities for the survival of human race. It is also important for the progress of the nation and essential factor for economic development. In other words, the absence of access to energy has a negative impact on human race and any country's economic development. The use of solar energy technologies nowadays is increasing in the world and most of the countries are trying to follow the move [1]. This has resulted in studies in order to assess the energy potentials and also show the need to use renewable energies in order to protect our planet and the environment around us [1,2]. Sustainable deployment and implementations of any energy projects and diversification of energy for generation mix within any country, the first step involves identifying and assessing the energy source potentials of that country [1, 3, 4]. However, in most developing countries like Zambia the availability of solar energy resource information is limited due to lack of wide distribution of meteological stations for collecting weather data across the country [1]. This has resulted in little research and challenges in thorough assessment of solar energy potential in the country. As such, satellite solar datasets are the best alternative to use for assessing solar energy potential for most developing countries $[3,4,5]$. Satellite datasets have been used in many researchs and have showed that there was good correlation with the local measured datasets $[4,6]$. 
The paper aims at studying and assessing the solar energy source distribution and potential in Zambia. For this purpose, the paper focuses on assessing the solar energy potential for nine provincess that makes up Zambia. As the country is targeting to reach sustainable development goals with the target of increasing access to energy for rural and urban areas in Zambia [7], therefore, this study is a must and very important for decision making, generation mix, and deployment of various solar energy technologies in the country.

The rest of the paper is structured as follows. In section II, a brief description of study area is given, followed by the description of energy sector in Zambia in section III. The section IV focuses on stating the renewable resources in Zambia. While section $\mathrm{V}$ focuses on the methodology and data collection and section VI deals with the models used. The section VII mainly focuses on the analysis of the results and finally the conclusion of the paper is summarized in section VIII.

\section{The Study Area}

\subsection{Geographic Description}

Zambia is located in the heart of Southern Africa at the latitude of 8 to 18 degrees south of the equator and longitude 22 to 34 degree east of prime meridian with an area of 752,614 square kilometers [8]. Over 98.77\% of Zambia's surface is taken up by land leaving only $1.23 \%$ covered by surface water such as rivers, streams, lakes and other inland water. It has no access to the sea or ocean. The country is surrounded by eight neighboring countries namely; Tanzania and Democratic Republic of Congo (DR Congo) to the North, Angola to the West and Namibia to the South West; Botswana and Zimbabwe to the South; and Mozambique and Malawi to the east as shown in fig. 1 below [8, 9]. It is divided into nine provinces with 72 districts, namely; Lusaka, Southern, Eastern, Western, North Western, Copperbelt, Central, Luapula and Northern provinces as shown in fig. 2. It has a population of approximately $14,638,510$ people (2014 estimates) of which 58\% lives in rural area and $42 \%$ lives in urban areas $[8,10,11]$. According to $[8,12]$, only about $3 \%$ of the rural population are electrified leaving the majority of the population to depend on wood fuel and other traditional energy sources for their household energy needs. This lack of access to electricity and modern services undermines the pace and scope of economic development in the nation. Furthermore, it is also one of the major obstacles for poor people in Zambia to move away from poverty and take development into their own hands and upgrade their quality of life. This has also caused unimaginable deforestation and desertification of the woodland to almost irreversible levels in some parts of the country [13].

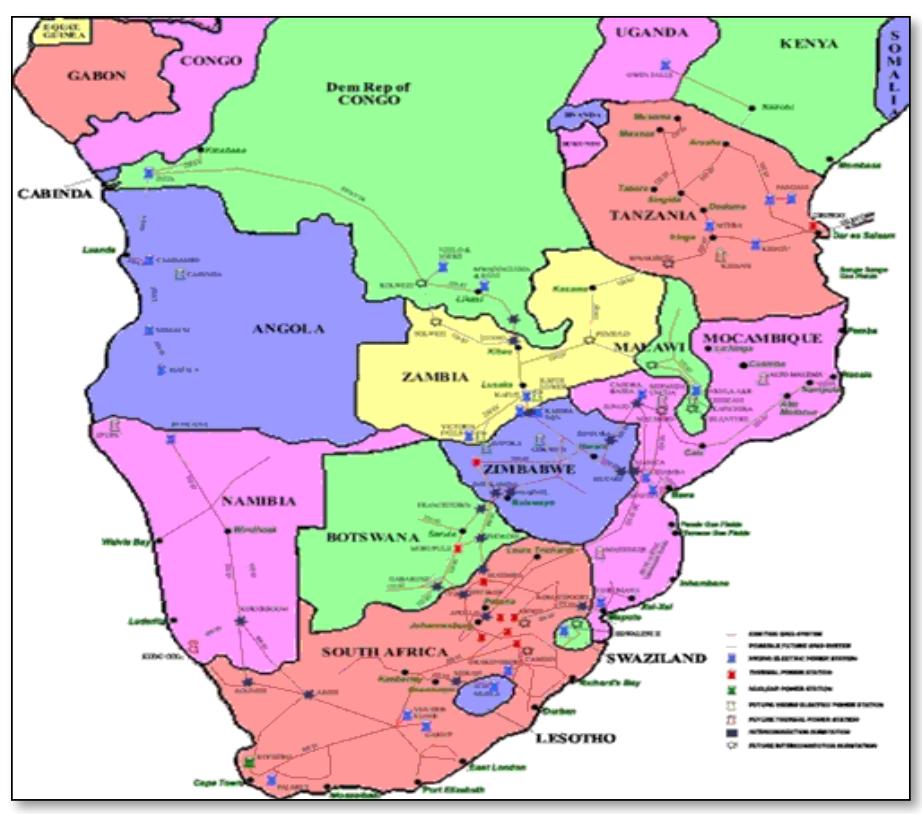

Figure 1. Zambia Location and Neighboring Countries and International Grid [7, 14] 


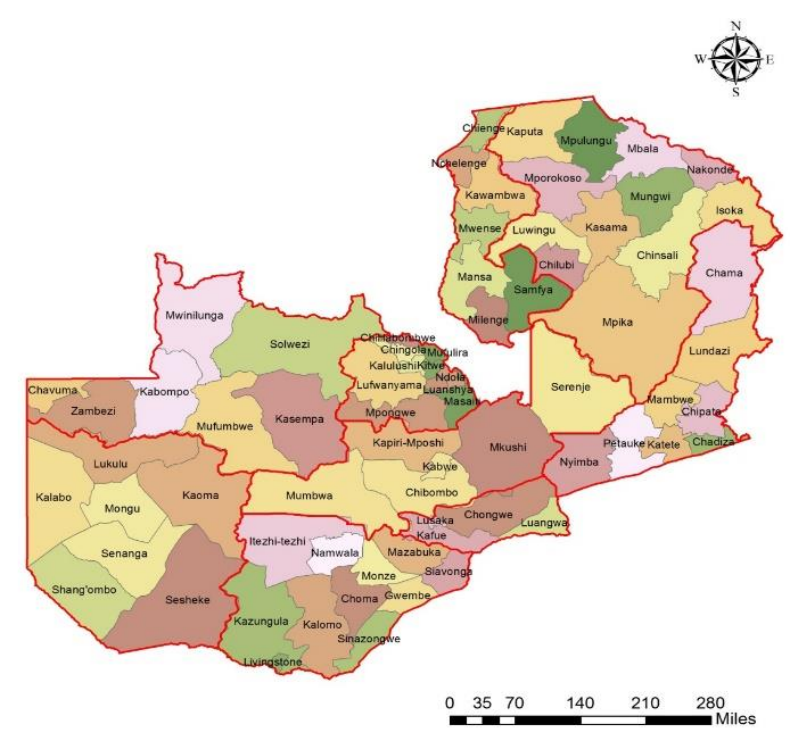

Figure 2. The Provinces and Districts in Zambia

\subsection{Electricity Industry in Zambia}

The electricity supply industry in Zambia mainly comprises of a vertically integrated state utility, Zesco, and an energy service company Copperbelt Energy Corporation (CEC) that purchases power from Zesco and supplies it to the mines $[15,16]$. In addition, two Independent Power Producer, Lunsemfwa Hydro Power Company (LHCP) and Zengamina Power Company (ZPC) and some small-scale solar based energy service companies supplying power to some rural areas also participate in the industry. Zesco currently dominates electricity generation, transmission, distribution and supply in Zambia [13].

\subsubsection{Electricity Supply}

The electricity supply in Zambia originated in 1960 when a small thermal station was built in Livingstone to serve a section of the town. Since then the supply system has grown, as of 2013, the country have installed capacity estimated at $2000 \mathrm{MW}$ [15]. However, the generation available out of the installed capacity is $1895 \mathrm{MW}$ of which about $90 \%$ comes from hydro source. Of the total installed capacity about $93 \%$ and most of off-grid installed capacity are owned by Zesco. LHCP and CEC are the biggest private operators in the country owning a capacity of $52.5 \mathrm{MW}$ and $80 \mathrm{MW}$ respectively. While ZPC is one of the smallest private operator owning a capacity of $750 \mathrm{~kW}$ off-grid system and supplying electricity to 745 customers in NorthWestern Province. Table 1 summaries the main players in electricity sector in Zambia [13].

Table 1. Main Players in Electricity Sector [17]

\begin{tabular}{|c|c|c|c|}
\hline $\begin{array}{l}\text { Power } \\
\text { Station }\end{array}$ & $\begin{array}{c}\text { Capacity } \\
\text { (MW) }\end{array}$ & $\begin{array}{c}\text { Type of } \\
\text { Technology }\end{array}$ & Operator \\
\hline Kafue Gorge & 990 & Hydro & \multirow[t]{5}{*}{ Zesco } \\
\hline $\begin{array}{l}\text { Kariba } \\
\text { North Bank }\end{array}$ & 1080 & Hydro & \\
\hline Victoria falls & 108 & Hydro & \\
\hline Lusiwasi & 12 & Hydro & \\
\hline Off-Grid & 49 & Hydro/Diesel & \\
\hline Lusemfwa & 28 & Hydro & \multirow[t]{2}{*}{ LHPC } \\
\hline Mulungushi & 24 & Hydro & \\
\hline Gas Turbine & 80 & Gas & CEC \\
\hline Off-grid & 0.75 & Hydro & $\mathrm{ZPC}$ \\
\hline Off-Grid & 0.06 & Solar PV & REA \\
\hline
\end{tabular}

\subsubsection{Energy Demand}

The electricity consumption in Zambia has been rising steadily estimated at approximately $6 \%$ per year (150$200 \mathrm{MW})$. The peak demand varies depending on the season; the winter peak demand was about $1450 \mathrm{MW}$ 
while the summer peak demand was about 1400MW as in 2009. However, in 2014 the peak demand was forecasted to be between $2,260 \mathrm{MW}$ and $2,612 \mathrm{MW}[16,18]$. The energy demand is expected to reach 16.6TWh by fiscal year 2020 and 21.6TWh in fiscal year 2030 respectively [19, 20].

As in many other Sub-Saharan African Countries, traditional wood fuel such as charcoal and firewood has remained the major energy source in Zambia contributing about $70 \%$ to the total energy demand [8, 13]. While, hydropower contributes about $14 \%$ to the total energy use and it is the second most used source. Petroleum products accounts for about $12 \%$ of the national energy demand. However, coal contributes a small share of about $2 \%$ to the total energy supply, despite its good potential in the southern province. Other energy sources such as renewable energy only contribute about $2 \%$ to the total energy balance in Zambia. Figure 1 summarizes the contribution of different types of energy sources [13].

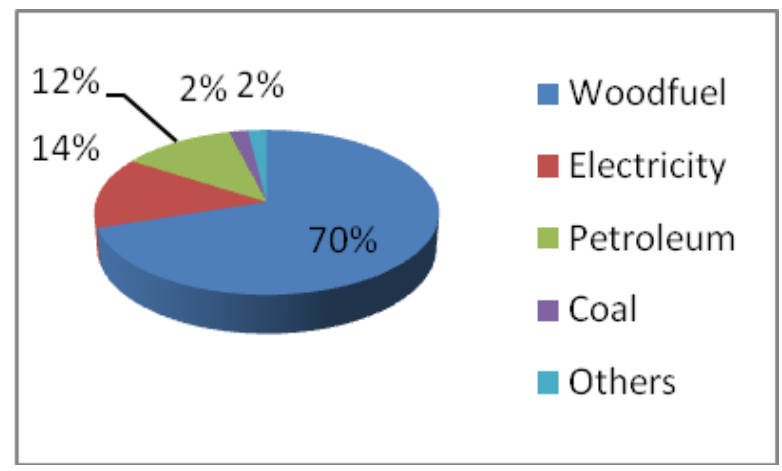

Figure 3. Total Primary Energy Supply [13, 17]

\subsection{Renewable Energy Resources}

\subsubsection{Hydropower}

The existing estimates of hydro potential in Zambia stands at about 6,000 MW excluding small, mini and micro hydro potential, which is estimated at 45MW [21]. Only about 30\% of the estimated Zambia's hydro potential has been harnessed. The Government of Zambia through Rural Electrification Authority has identified 29 locations of mini hydro schemes in the North-Western and Northern Luapula provinces of Zambia. Nonetheless, in order to increase harnessing power from hydro, the government of Zambia is /has continued studying the development of several projects as listed in table 1 below [15].

Table 2. Hydro Potential Sites in Zambia [13, 15, 16, 19]

\begin{tabular}{|l|c|c|}
\hline River & Description & Capacity (MW) \\
\hline Kafue & Kafue Gorge Lower & 750 \\
\cline { 2 - 3 } & Itezhi Tezhi & 120 \\
\hline Kalungwishi & Kalungwishi Hydro & 247 \\
\hline Luangwa & Lusiwasi Extension & 40 \\
\hline Kabompo & Kabompo Gorge & 40 \\
\hline Luapula & Mambilima Falls & 698 \\
\cline { 2 - 3 } & Mombututa Gorge & 490 \\
\cline { 2 - 3 } & Lunangwe falls & 96 \\
\hline Zambezi & Batoka Gorge & 1600 \\
\cline { 2 - 3 } & Devil's Gorge & 1000 \\
\cline { 2 - 3 } & Mpata Gorge & 543 \\
\cline { 2 - 3 } & Chavuma Falls & $10-20$ \\
\cline { 2 - 3 } & Ngonye Falls & 80 \\
\hline Lufubu & Lufubu & 80 \\
\hline & Mulembo/Lelya & 280 \\
\hline Mita Hills Reservoir & Muchinga & 230 \\
\hline Mpika & Mutinondo/Luchenene & 70 \\
\hline
\end{tabular}

\subsubsection{Biomass}

Conversion of Biomass to electrical power potential stands at $500 \mathrm{MW}$ of which $447 \mathrm{MW}$ could be from Agro wastes, $46 \mathrm{MW}$ from forest wastes and 4MW from municipal wastes [19]. Currently Zesco in 
conjunction with Global Environment Facility (GEF) /United Nations Industrial Development Organization (UNIDO) plans to install a $1 \mathrm{MW}$ biomass power plant in Kaputa District in order to replace the current 440kW diesel power plant [7, 19, 22]. Furthermore, according to feasibility done by SNV and Hivos in 2012 shows that sixteen (16) of the country's 72 districts have biogas potential (livestock manure) for electricity generation $[21,23]$.

\subsubsection{Geothermal}

Estimates further indicate that Zambia has potential of generating electricity from geothermal sources; the country has 80 hot springs, of which 35 have potential for power production. Currently, the Government of Zambia is considering constructing a $2 \mathrm{MW}$ of geothermal power plant in Kapisya, Western Shore of Lake Tanganyika. At present, there is only one small-scale $240 \mathrm{~kW}$ pilot project that was developed with the support of Italy in $1987[7,19]$.

\subsubsection{Solar}

According to the previous studies and data undertaken by Meteorological Department of Zambia, the country has a significant potential of solar energy for both power production and thermal from solar energy technologies. The country is situated at the latitude of 8 to 18 degrees south of the equator and longitude 22 to 34 degrees east of prime meridian with an average sunshine of about 6-8hours per day and high monthly average solar radiation incident rate of $5.5 \mathrm{kWh} / \mathrm{m}^{2} /$ day throughout the year $[7,13,19,24]$.

To show its comment in increasing access to energy, the Government of Zambia through Rural Electrification Authority (REA) has embanked in PV projects such as installation of a $60 \mathrm{~kW}$ solar Off-min grid in Mpanta, Samfya district of Luapula Province, which is supplying about 50 households [24]. Furthermore, REA has installed about 250 solar PV systems in schools and buildings of traditional authorities as well as 400 solar home systems under the Energy Service Companies (ESCO) pilot project [7, 13, 24].

However, a thoroughly assessment of the solar energy potential in terms of distribution and extractable potential for energy generation throughout the country has not been done. For this reason, this study is important to undertake a thorough assessment of solar energy potential in Zambia in order to help the decision makers and accelerate RETs deployment in the country [7].

\subsubsection{Wind}

The country has an ideal plateau landscape which offers some locations where there is potential for wind energy exploitation. This wind energy as a potential area for power generation has not been exploited due to among other reasons the few studies on wind and lack of wind atlas. However, despite the absence of a comprehensive wind atlas for the country, meteorological data recorded over the past three decades indicates that the country has generally untapped wind energy. Estimates measured at height of 10meters indicates that most parts of the country have the wind speed average of $3 \mathrm{~m} / \mathrm{s}$, the Western Province and Kasama in Northern Province are nonetheless areas with high wind speed with averages of $6 \mathrm{~m} / \mathrm{s}$ suitable for power production [7, 19, 25].

\section{Materials and Method}

There are four main types of solar energy potential assessment, namely: resource potential, technical potential, economic potential and market potential as shown in fig.4 [26]. However, currently the assessment of solar energy potential in many countries including Zambia often results only in theoretical resource potential (resource potential) which only indicate the amount of radiation at the country's surface [1,13, 27]. However, for decision making and sustainable deployment of solar energy technologies, it is extremely important to know how much of the available resource potential is extractable for use i.e. technically in terms of capacity and generation. In addition, it is also vital to know how much of the country's surface area is available and suitable for solar energy technology implementation [1,27]. 


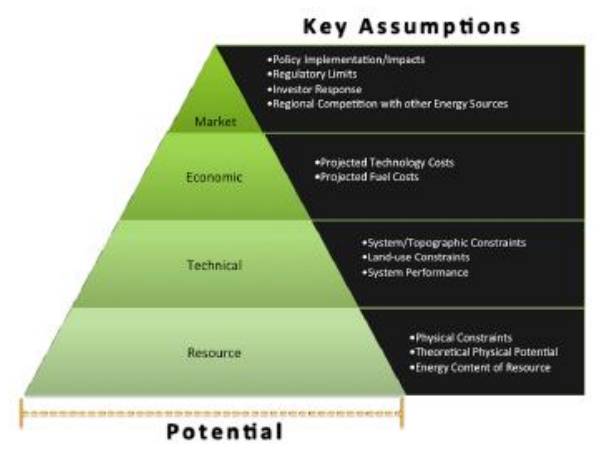

Figure 4. Levels of Solar Energy Potentials Assessments [26,28]

Thus, based on the previous works that were done in various countries the methodology used in this study is built. The methodology is aimed at assessing the solar energy potential that can be extracted for future energy generation mix in Zambia. The approach considers solar radiation, sunshine hours, available and suitable land areas for PV implementation and system performance [1,27]. The procedure involved four main steps and for analysis of the data, both simulation and analytical approach were adopted in this study.

Firstly, using ArcGIS the study area were divided into small Zones. Zambia is located at latitude 8 to 18 degree north of the equator and longitude 22 to 34 degrees east of prime meridian. Thus, for thorough assessment of the solar energy potential and its distribution within the country, the study area were divided into 130 zones, then several satellite datasets i.e. solar datasets were extracted within each zones from several points (square) which was made up of latitude and longitude [5].

Thereafter, data were prepared in excel for use in ArcGIS for spatial analysis, for solar source distribution assessment. The restricted areas for RET implementation were also extracted from various literatures [1, 29]. For simulation, both ArcGIS and Photovoltaic GIS software and analytical approach (excel) were used.

The outcomes of this study were the solar energy potential and its distribution within Zambia. To quantify the solar energy potential and its distribution within Zambia, the following factors were used; the Monthly average solar radiation [1, 2, 4, 21, 30, 31, 32, 33]. Monthly and Yearly Solar Energy Potential [21, 31], Solar Power density, Total Yearly Sunshine hours [1,31], Theoretical solar energy potential for Zambia [21] and Technical power and generation solar energy potential $[1,21,26]$ in Zambia considering available area for solar energy and other factors that affect PV technologies.

The final step involved analysis of the results to form the conclusion on the solar energy potential and its distribution in Zambia.

\subsection{Theory/Calculation Models}

\subsubsection{Array Model}

The technical solar energy potential is the energy produced by the arrays taking into consideration the efficiency of the PV technology and some other factors such as losses due to weather condition i.e temperature and dirt covering the module, and the losses due to power conditioning [16]. Therefore, the energy available for supply to grid has been calculated using (1) given as:

$$
E_{A C}=A_{P V} \cdot H_{R} \cdot \eta_{p}\left(1-\lambda_{p}\right)(1-\lambda \cdot C)
$$

Where $E_{A}$ is Energy output of PV system (kWh/year) $A_{P V}$ is Array Area $\left(\mathrm{m}^{2}\right), H_{R}$ is solar radiation on the module $\left(\mathrm{kWh} / \mathrm{m}^{2}\right.$-year), $\eta_{\mathrm{p}}$ is module efficiency, $\lambda_{\mathrm{p}}$ is miscellaneous module losses (i.e due to dirt covering assumed at $10 \%$ ), and $\lambda_{\mathrm{C}}$ is Power conditioning losses, assumed at $5 \%$.

Module efficiency is a function of its nomial efficiency, $\eta_{\mathrm{r}}$ which is measured at a reference temperature $\mathrm{T}_{\mathrm{r}}=25^{\circ} \mathrm{C}[16]$. It is calculated as:

$$
\eta_{p}=\eta_{r} \cdot\left[1-\beta\left(T_{c}-T_{r}\right)\right\rfloor
$$

Where $\beta$ is temperature coefficient for module efficiency, $T_{c}$ is module temperature, $T_{r}$ is reference temperature.

Module temperature is related to the average monthly ambient temperature $T_{a}[16,17]$ as given below: 


$$
T_{c} ;=30+0.0175(G t-300)+1.1(T a-25) .
$$

Where $\mathrm{G}_{\mathrm{t}}$ is Solar irradiance $\left(\mathrm{W} / \mathrm{m}^{2}\right), \mathrm{T}_{\mathrm{a}}$ is ambient Temperature $\left({ }^{0} \mathrm{C}\right)$, NOCT is Nominal Operating Cell Temperature, it depends on type of module used, and $\mathrm{T}_{\mathrm{a}}$ is ambient temperature $\left({ }^{0} \mathrm{C}\right)$.

\subsubsection{Capacity Factor Model}

The capacity factor is a model used to show the amount of energy delivered by an electric power generation system [4]. It is defined as the ratio of the output actual annual energy generated by PV system to the amount of energy the PV system would generate if it is operated continuously at full rated power for 8760 hours in a year and it has been evaluated using $(4)[4,26]$

$$
C F=\frac{E_{A C}}{8760 \times P_{P V}}
$$

Where CF is capacity factor (\%), $\mathrm{E}_{\mathrm{AC}}$ is Actual annual energy output (kWh/year), and $\mathrm{P}_{\mathrm{PV}}$ is Full rated PV power $\left(\mathrm{W}_{\mathrm{p}}\right)$.

\subsubsection{Solar Energy Potential Model}

\section{A. Theoretical Potential Model}

Theoretical solar enrgy potential involves the assessment of the solar energy that is received on the surface of the study area. This potential involves identifying the study area boundary and the size of the study land area, including annual average daily solar radiation magnitude. Thus, the theoretical potential has been calculated using (5) as expressed below;

$$
E_{T H}=A_{s} \cdot H_{P} \cdot T_{T S H}
$$

Where $E_{G}$ is Theoretical Solar energy potential (MWh/year), $A_{A D S}$ is Active Surface Area $\left(\mathrm{km}^{2}\right)$, $\mathrm{H}_{\mathrm{R}}$ is Solar Irradiance $\left(\mathrm{MW} / \mathrm{km}^{2}\right)$, and $\mathrm{T}_{\mathrm{T}}$ is Yearly total Sunshine hours (hours/year)

\section{B. Geographical Potential Model}

Geographical solar energy potential involves assessing the solar energy that is received on the available and suitable land area[21]. Thus, the process of assessing this potential involves firstly excluding the restricted land areas for solar energy technologies deployment and development such as agriculture areas, roads, surface water bodies areas, protected national parks, game reserves and forest reserves, areas under the transmission and distribution line and unsuitable land area for solar energy technologies deployment and development such as lands with bad slopes of more than $3 \%$ slopes, the unsuitable area has been estimated at $566,493 \mathrm{~km}^{2}$ according to literatures $[21,26]$. Therefore, the remaining land area is taken as the most suitable land area for solar energy technologies deployment. Thus, the geographical solar energy potential has been estimated using (6) as given below.

$$
E_{G}=A_{A O S} \cdot H_{R}
$$

Where $E_{G}$ is Geographical Solar energy potential (kWh/year), $A_{A D S}$ is Available Suitable Area $\left(\mathrm{m}^{2}\right)$, and $H_{R}$ is Total average yearly solar radiation $\left(\mathrm{kWh} / \mathrm{m}^{2}\right.$-year)

\section{Technical Potential Model}

Utility-scale photovoltaic is define as a large-scale PV power plant that can be deployed within the boundaries of the country on an open space [26]. The process of assessing the extractable energy potential from the sun for any country involves firstly by excluding areas not suitable for this technology within the defined boundaries $[21,26]$. Considering the estimated geographical potential and technical characteristics of PV generation systems to convert the solar energy to electrical energy, the country's available technical solar energy potential can be estimated as using (7) below [21, 26]:

$$
E_{T}=A_{A O S} \cdot p_{P D} \cdot C F . T_{T S H}
$$


Where $\mathrm{E}_{\mathrm{T}}$ is Solar Energy Potential (MWh/year), $\mathrm{A}_{\mathrm{ADS}}$ is Study Area Available Suitable Area $\left(\mathrm{km}^{2}\right), \mathrm{P}_{\mathrm{PD}}$ is Study Area Power density $\left(\mathrm{MW} / \mathrm{km}^{2}\right), \mathrm{CF}$ is Study Area Capacity factor $(\%)$, and $\mathrm{T}_{\mathrm{TSH}}$ is total hours in a year (8760).

\section{Results and Discussion}

Fig. 5 shows that the solar source across the country is not evenly distributed as it is a case in most countries due to geographical differences. However, most of the districts in Zambia receives higher annual average daily solar radiations with the lowest solar radiation of $5.51 \mathrm{kWh} / \mathrm{m}^{2}$-day and highest of $6.23 \mathrm{kWh} / \mathrm{m}^{2}$-day in fewer places. Thus, it can be noted that, all the districts in Zambia have potential for deployment of any type of solar energy technologies for various applications.

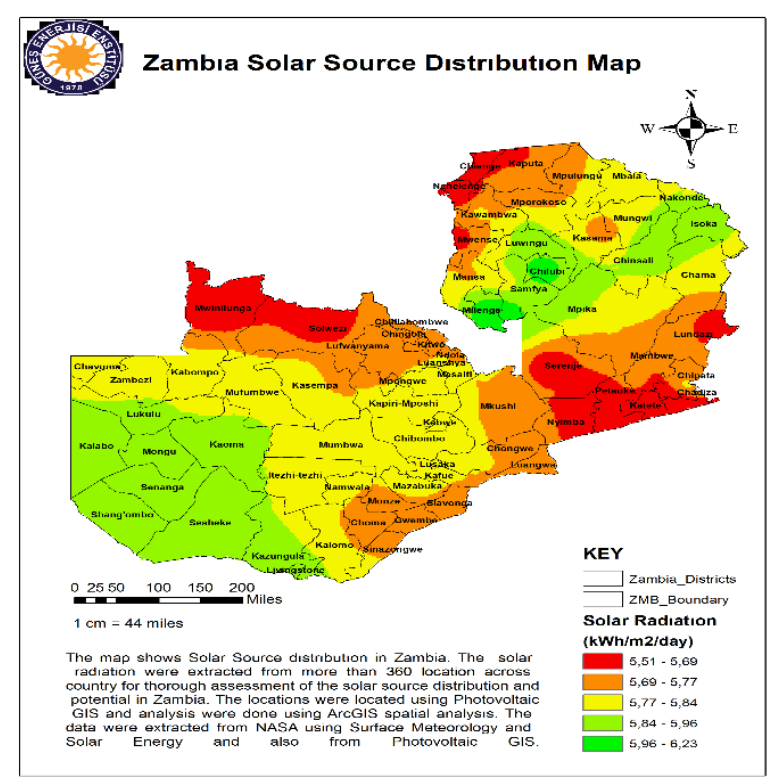

Figure 5. Solar Source Distribution and Potential in Districts of Zambia

Fig. 6 shows that most of the provinces in Zambia have radiations above country's annual average radiations of $5.78 \mathrm{kWh} / \mathrm{m}^{2}$-day, with Western, Southern, Northen, and part of Luapula provinces having the most attractive annual average radiation above $5.80 \mathrm{kWh} / \mathrm{m}^{2}$-day. It further shows that the country receives the annual solar radiation which rangs from 5.51 to $6.23 \mathrm{kWh} / \mathrm{m}^{2}$-day.

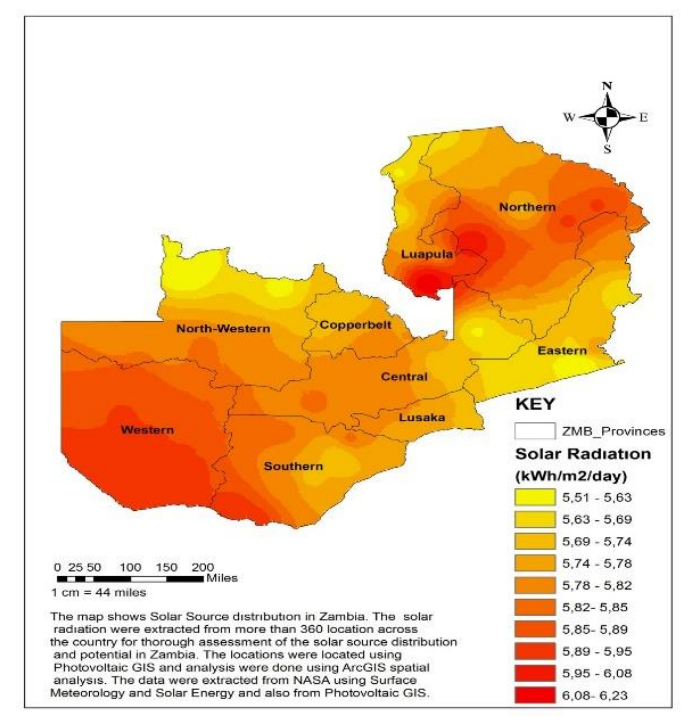

Figure 6. Spatial Annual Solar Source Distribution for Zambia 
The study of monthly variability of solar radiation in the Provinces and Zambia is very important for planning the power grid management and monthly generation mix [21]. Fig. 7 compares the provincial variability of monthly average daily solar radiation. It is worth to note changes in solar radiation for Luapula and Southern provinces, that while the solar radiation in Luapula start raising up, in Southern Province the radiation start droping until the month of June then it start raisiing again until October while for Luapula the radiation continues raising until months of august and september then starting droping until december. This behave shows the need of wide deployment of solar energy technologies in all provinces for optimal ultilazition of solar energy.

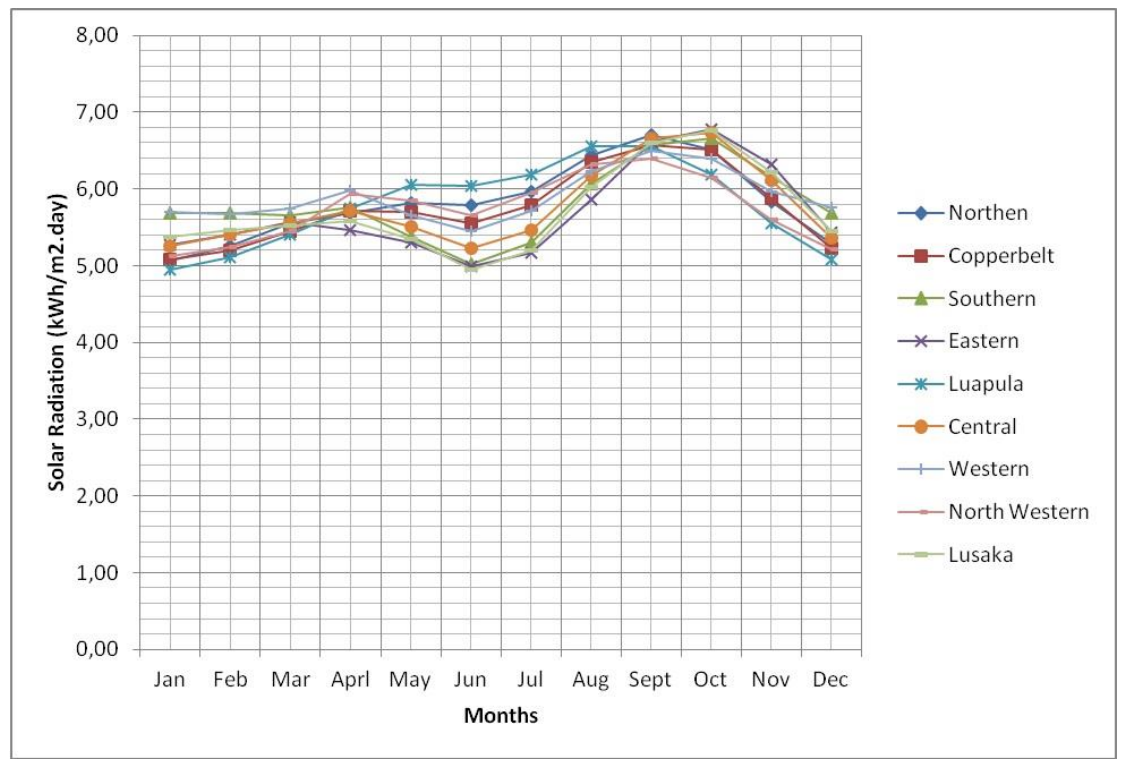

Figure 7. Comparison of Provincial Variability of Monthly average Daily Solar Radiation

Table 3. Comparison of Theoretical Potential of Solar Energy in Provinces

\begin{tabular}{|l|c|c|c|c|c|c|}
\hline Province & $\begin{array}{c}\text { Total } \\
\text { Surface } \\
\text { area }\left(\mathbf{k m}^{2}\right)\end{array}$ & $\begin{array}{c}\text { Total Yearly Average } \\
\text { Solar Radiation } \\
\left(\mathbf{k W h} / \mathbf{m}^{2} \mathbf{- y r}\right)\end{array}$ & $\begin{array}{c}\text { Total Yearly } \\
\text { Average Sunshine } \\
\text { Hours }(\mathbf{h r} / \mathbf{y r})\end{array}$ & $\begin{array}{c}\text { Solar Power } \\
\text { Density } \\
(\mathbf{M W / k m})\end{array}$ & $\begin{array}{c}\text { Theoretical } \\
\text { Solar Power } \\
(\mathbf{T W})\end{array}$ & $\begin{array}{c}\text { Theoretical Solar } \\
\text { Energy Potential } \\
(\mathbf{T W h} / \mathbf{y r})\end{array}$ \\
\hline Luaska & 21,896 & 2080,50 & 4405,55 & 472,25 & 10.340 & 45,555 \\
\hline Luapula & 50,567 & 2111,26 & 4401,90 & 479,62 & 24.253 & 106,759 \\
\hline Central & 94,394 & 2103,01 & 4401,90 & 477,75 & 45.097 & 198,512 \\
\hline Copperbelt & 31,328 & 2098,02 & 4401,90 & 476,62 & 14,932 & 65,729 \\
\hline Eastern & 69,208 & 2073,20 & 4401,90 & 470,98 & 32.596 & 143,484 \\
\hline Western & 126,386 & 2151,41 & 4401,90 & 488,75 & 61.771 & 271,910 \\
\hline Southern & 85,823 & 2116,34 & 4401,90 & 480,78 & 41.262 & 181,631 \\
\hline Northen & 147,186 & 2126,73 & 4405,55 & 482,74 & 71.053 & 313,028 \\
\hline $\begin{array}{l}\text { North } \\
\text { Western }\end{array}$ & 125,826 & 2093,54 & 4405,55 & 475,21 & 59.794 & 263,425 \\
\hline Zambia & $\mathbf{7 5 2 , 6 1 4}$ & $\mathbf{2 1 0 9 , 9 7}$ & $\mathbf{4 4 0 3 , 1 2}$ & $\mathbf{4 7 9 . 1 9}$ & $\mathbf{3 6 0 . 6 4 5}$ & $\mathbf{1 , 5 8 7 , 9 6 3}$ \\
\hline
\end{tabular}

Table 3 above shows the theoretical solar energy potential in the different provinces of Zambia. It can be noticed that Northern Province, despite having lower yearly radiation as compared to Western Province, it has highest theoretical solar energy potential which is due to its larger surface area.

Fig. 8 below shows the provincial and monthly variability of highest Monthly average solar radiation in Zambia.It can be noticed that the month with the highest solar radiation across the Zambia changes monthly and with location, this therefore shows the importance of need to distribute the solar energy technologies across the country in order to optimize the solar energy potential. 


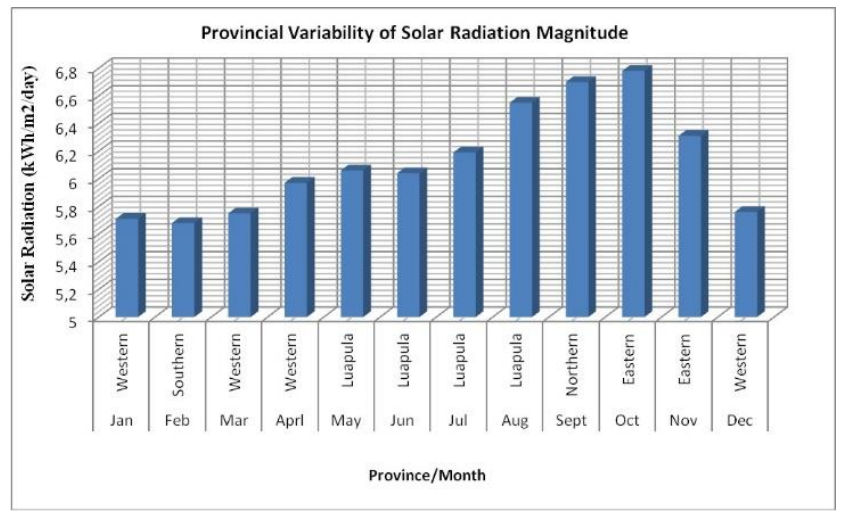

Figure 8. Provincial and Season Variability of Highest Solar Radiation

Most of the provinces in Zambia have high solar radiation (fig. 9) above $5.7 \mathrm{kWh} / \mathrm{m}^{2}$-day except Eastern and Lusaka provinces.

Thus, the country can be classified into three regions, low radiation regions with radiations below country's annual average daily solar radiation of $5.78 \mathrm{kWh} / \mathrm{m}^{2}$-day, medium radiation regions with average radiations same as the country's annual average solar radiation of $5.78 \mathrm{kWh} / \mathrm{m}^{2}$-day and higher radiation regions with radiation above country's annual average daily solar radiations of $5.78 \mathrm{kWh} / \mathrm{m}^{2}$-day. These radiations correspond to a theoretiical energy production between 2073,20 and $2151.41 \mathrm{kWh} /\left(\mathrm{m}^{2}\right.$-year). In addition, fig. 10 shows that the country can further be divided into two regions, long sunshine hours regions with sunshine hours above $12.06 \mathrm{hrs}$ and short sunshine hours regions with sunshine hours below 12.06hours.

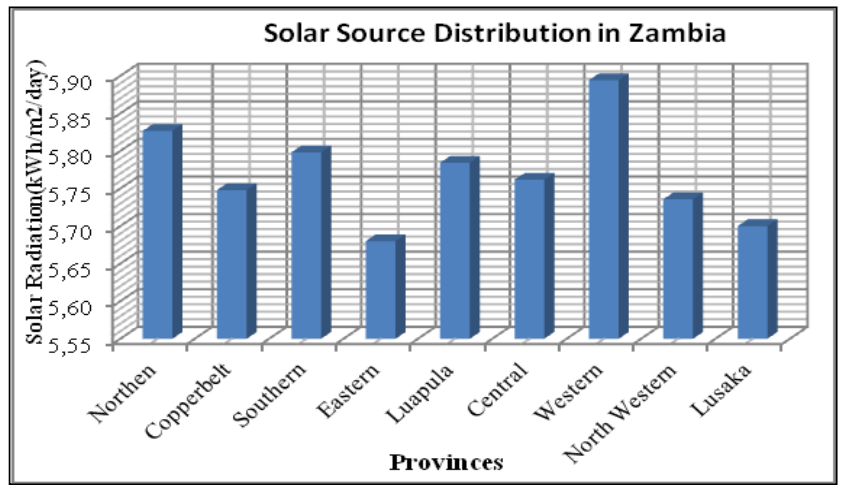

Figure 9. Provincial Annual Solar Radiation

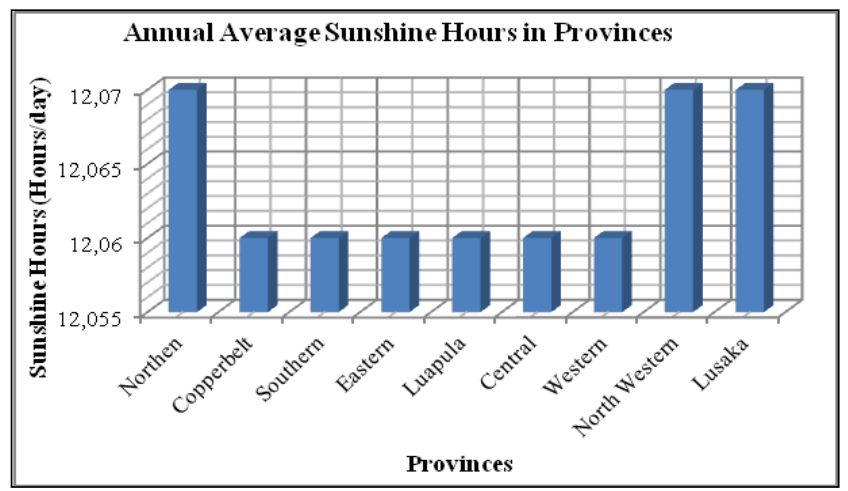

Figure 10. Provincial Sunshine hours

Fig, 11 and 12 shows the national variability of monthly average of solar radiation and sunshine hours. Table 4 shows the natioanl monthly average of daily solar radiation, sunshine hours, maximum air temperature, clearness index and wind speed. It can be noted that the country receives maixmum solar radiation, wind speed and temperatures in the months of september and october and minimum solar radiations in the months of January, June and December. While the long sunshine hours are experienced in the months of december 
and shortest in June. The country has solar irradiance of $479.19 \mathrm{~W} / \mathrm{m}^{2}$ and receives the annual average solar radiation of $5.78 \mathrm{kWh} / \mathrm{m}^{2}$-day and total yearly solar radiation of $2109,97 \mathrm{kWh} / \mathrm{m}^{2}$-year with total yearly sunshine hours of about 4403,12hours per year as shown in table 3 and 4.

Table 4. Variability of Monthly Average Solar Radiation and Sunshine hours in Zambia

\begin{tabular}{|l|c|c|c|c|c|}
\hline Month & Sunshine Hours (hr/day) & $\begin{array}{c}\text { Solar Radiation } \\
\left(\mathrm{kWh} / \mathrm{m}^{2}-\mathrm{d}\right)\end{array}$ & $\mathrm{T}\left({ }^{\circ} \mathrm{C}\right)$ & $\mathrm{K}$ & Monthly Ave. Wind Speed (m/s) \\
\hline Jan & 12,77 & 5,27 & 25,08 & 0,46 & 2,94 \\
\hline Feb & 12,47 & 5,37 & 25,44 & 0,48 & 2,94 \\
\hline Mar & 12,10 & 5,55 & 25,58 & 0,53 & 2,90 \\
\hline Aprl & 11,77 & 5,74 & 25,96 & 0,61 & 3,36 \\
\hline May & 11,46 & 5,65 & 23,31 & 0,68 & 3,41 \\
\hline Jun & 11,31 & 5,46 & 23,37 & 0,70 & 3,64 \\
\hline Jul & 11,37 & 5,69 & 23,39 & 0,71 & 3,93 \\
\hline Aug & 11,63 & 6,25 & 25,99 & 0,70 & 4,22 \\
\hline Sept & 11,99 & 6,58 & 29,48 & 0,66 & 4,66 \\
\hline Oct & 12,35 & 6,50 & 29,89 & 0,60 & 4,24 \\
\hline Nov & 12,68 & 5,94 & 27,86 & 0,53 & 3,78 \\
\hline Dec & 12,86 & 5,39 & 25,57 & 0,47 & 3,27 \\
\hline Annual & $\mathbf{1 2 , 0 6}$ & $\mathbf{5 , 7 8}$ & $\mathbf{2 6 , 0 7}$ & $\mathbf{0 , 6 0}$ & $\mathbf{3 , 6 1}$ \\
\hline Yearly & $\mathbf{4 4 0 3 , 2 3}$ & $\mathbf{2 1 0 9 , 9 7}$ & & & \\
\hline
\end{tabular}

T-Average Maximum Air Temperature

K-Clearness Index

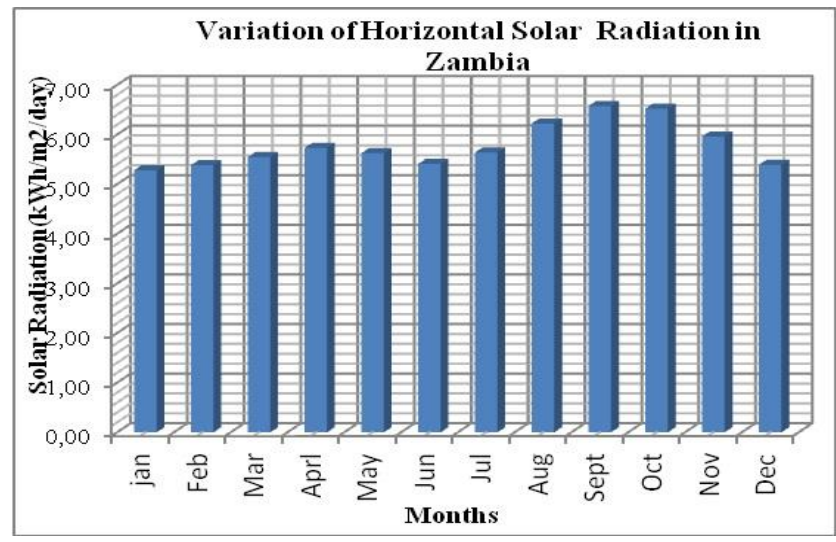

Figure 11. National Variability of Monthly Average Daily Solar Radiation

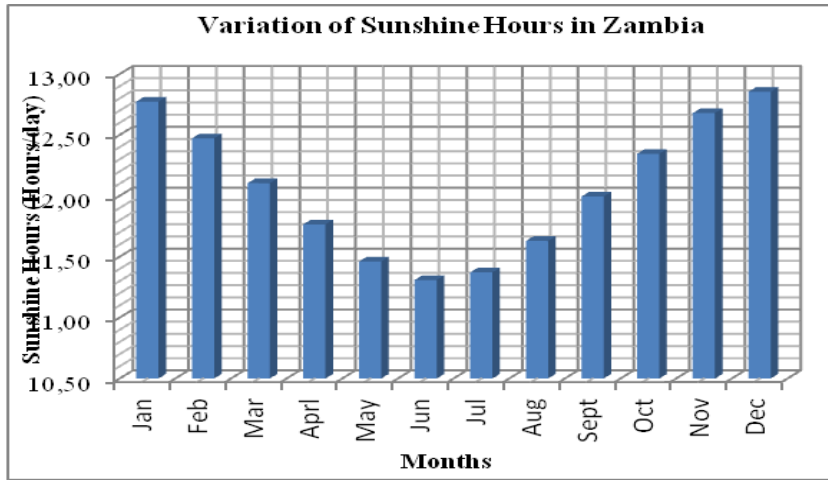

Figure 12. National Variability of Monthly Average Daily Sunshine Hours

Table 5 below presents the details of module used to analyze the technical potential. Table $6 \mathrm{a}-6 \mathrm{~b}$ below summarizes the results of the study, showing the total estimated available area, theoretical, geographical and technical solar energy generation and capacity potential in Zambia. Zambia has on average solar energy potential of $2109,97 \mathrm{kWh} / \mathrm{m}^{2}$-year with average sunshine of 4403,12 hours per year. It has a total suitable land area for utility-scale PV implementation of about $186,121 \mathrm{~km}^{2}$ which accounts for $24.73 \%$ of the Zambia's 
total surface area. This area corresponds to geographical solar energy potential of 392,701TWh per year. Taking into consideration capacity factor which is estimated at $22.55 \%$ using Polycrystalline PV technologies and power density of $55.6 \mathrm{MW} / \mathrm{km}^{2}$ the country has technical solar energy potential of about $20,442 \mathrm{TWh} /$ year.

Table 5. PV Module Parameters (Polycrystalline Silicon) [34]

\begin{tabular}{|l|c|}
\hline Item & Parameter \\
\hline PV Module Max.Power $\left(\mathrm{W}_{\mathrm{P}}\right)$ & 250 \\
\hline Optimum Power Voltage $\mathrm{V}_{\mathrm{MPP}}(\mathrm{V})$ & 30.3 \\
\hline Optimum Operating Current $\mathrm{I}_{\mathrm{MPP}}(\mathrm{A})$ & 8.25 \\
\hline Open Circuit Voltage $\mathrm{V}_{\mathrm{OC}}(\mathrm{V})$ & 37.3 \\
\hline Short Circuit Current $\mathrm{I}_{\mathrm{SC}}(\mathrm{A})$ & 8.69 \\
\hline PV Module Area $\left(\mathrm{m}^{2}\right)$ & 1.64 \\
\hline PV Module efficiency $(\%)$ & 15.24 \\
\hline Temperature Coefficient $\mathrm{P}_{\max }\left(\% /{ }^{\circ} \mathrm{C}\right)$ & -0.47 \\
\hline Nominal Cell Operating Temperature $\left({ }^{\circ} \mathrm{C}\right)$ & 25 \\
\hline
\end{tabular}

Table 6a. Solar Energy Potential in Zambia

\begin{tabular}{|c|c|c|c|c|}
\hline Available Suitable Area & Annual Average & Solar Energy Potential & Sunshine Hours & Solar Power Density \\
\hline $\mathrm{km}^{2}$ & $\mathrm{kWh} / \mathrm{m}^{2} \mathrm{~d}$ & $\mathrm{kWh} / \mathrm{m}^{2} \mathrm{a}$ & $\mathrm{Hrs} / \mathrm{a}$ & $\mathrm{MW} / \mathrm{km}^{2}$ \\
\hline $\mathbf{1 8 6 , 1 2 1}$ & $\mathbf{5 , 7 8}$ & $\mathbf{2 1 0 9 , 9 7}$ & $\mathbf{4 4 0 3 , 1 2}$ & $\mathbf{5 5 , 6}$ \\
\hline
\end{tabular}

Table 6b. Solar Energy Potential

\begin{tabular}{|l|c|c|}
\hline Energy Potential & Power(TW) & Energy(TWh/a) \\
\hline Theoretical & 360.645 & $1,587,964$ \\
\hline Geographical & 89.187 & 392,701 \\
\hline Technical & 10.248 & 20,442 \\
\hline
\end{tabular}

\section{Conclusion}

The study has presented the view of the theoretical, geographical and technical potentials of solar energy and its distribution in Zambia. The data used in the study were extracted from NASA using Surface Meteorology and Solar Energy and then analyzed. The study has shown that, the country have high technical potential of solar energy for PV electricity generation and various applications. It has also presented variability and ranges of magnitude of monthly average daily solar radiation in Zambia. From the results presented in the study, it shows that the daily solar radiation in Zambia varies depending on season changes. The analyzed results also show that Western province has the highest annual average solar radiation of $5.89 \mathrm{kWh} / \mathrm{m}^{2}$-day while the Eastern province has the lowest radiation of $5.68 \mathrm{kWh} / \mathrm{m}^{2}$-day. It can be noticed that almost all the provinces in Zambia experience a good solar radiation ranges. The Western province has an annual average solar radiation range of $5.44-6.50 \mathrm{kWh} / \mathrm{m}^{2}$-day, while Eastern province experiences the range of $4.99-6.78 \mathrm{kWh} / \mathrm{m}^{2}$ day. On the other hand, the Southern and Northern provinces have an annual average solar radiation ranges of $5.03-6.66 \mathrm{kWh} / \mathrm{m}^{2}$-day and $5.07-6.70 \mathrm{kWh} / \mathrm{m}^{2}$-day respectively. Meanwhile, the Northwestern province experiences an annual average solar radiation range of $5.13-6.40 \mathrm{kWh} / \mathrm{m}^{2}$-day and Central province receives an annual average solar radiation range of $5.23-6.74 \mathrm{kWh} / \mathrm{m}^{2}$-day. Furthermore, the Copperbelt province and Luapula province experiences an annual average solar radiation of ranges $5.08-6.57 \mathrm{kWh} / \mathrm{m}^{2}$-day and 4.95 $6.55 \mathrm{kWh} / \mathrm{m}^{2}$-day respectively. However, the country generally, receives annual average dialy solar radiation of $5.78 \mathrm{kWh} / \mathrm{m}^{2}$-day at ambient temperature of $26.07^{\circ} \mathrm{C}$ with clearness index of 0.60 and wind speed of $3.61 \mathrm{~m} / \mathrm{s}$. In addition, the country experiences a total yearly average solar energy of $2109.97 \mathrm{kWh} / \mathrm{m}^{2}$-year with yearly total avarage sunshine of 4403.12 hours. Having the total surface area of $752,614 \mathrm{~km}^{2}$, the country has a theorectical solar energy potential of 1.59 million TWh per year on the horizontal surface. The total estimated solar energy geographical and technical potential for utility-scale photovoltaic technology are $392,701 \mathrm{TWh} /$ year and 20,442TWh/year respectively. Zambia has higher estimated technical potential due to relatively high solar radiation, sunshine hours, good temperatures and the availability of large suitable flat land areas for PV technology deployment. With an ever increasing population, deforestation, energy demand, and droughts which is affecting the hydropower systems which is the main source for electrical energy in the country, solar energy appears to be one of the best effective solution for production of sustainable and clean energy in energy generation mix in Zambia. 


\section{Acknowledgements}

The authors are grateful to University of Zambia and Turkish Government for financial support.

\section{References}

[1] LIU Guangxu, WU Wenxıang, GE Quansheng, DAI Erfu, WAN Zhıwe1, ZHOU Yang, 2011,'GIS-based assessment of roof-mounted solar energy potential in Jiangsu, China',2011 Second International Conference on Digital Manufacturing and Automation.

[2] Ahmed Belhamadia, Muhamad Mansor, Mahmoud A.Younis, 2013, 'Assessment of Wind and Solar Energy Potentials in Malaysia', 2013 IEEE Conference on Clean Energy and Technology (CEAT).

[3] L.M. Ayompe, A.Duffy, 2014, An assessment of the energy generation potential of photovoltaic systems in Cameroon using satellite-derived solar radiation datasets, Sustainable Energy Technologies and Assessments 7 (2014) 257-264, ScienceDirect.

[4] M.Pendieu Kwaye, J.Bendfeld, N.Anglani, 2015, 'Assessment of Renewable Energy Resources in Cameroon and Special Regards on Energy Supply'.

[5] Chumnong Sorapipatana, 2010, An assessment of solar energy potential in Kampuchea', Renewable and Sustainable Energy Review 14(2010) 2174-2178 ScienceDirect.

[6] Njomo D, Wald L, 2006, "Solar radiation retrieval in Cameroon from Meteosat satellite imagery using the Heliosat_2 method", Sci Technol Vis 2006; 2(1): 19-24.

[7] Gauri Singh, Safiatou Alzouma Nouhou, Mohamed Youba Sokana, 2013, "Zambia Renewable Readiness Assessment” International Renewable Energy Agency (IRENA) 2013 report.

[8] Likonge Makai, Marta Molinas (2013). Biogas-An Alternative Household Cooking Technique for Zambia", IEEE Conference, 2013.

[9] Prof. Dr. Imasiku A. Nyambe, Miriam Feilberg, "Zambia- National Water Resources Report for WWDR3; Theme-Water in a Changing World", Repubulic of Zambia, Ministry of Energy and Water Development. Pp 6-50

[10] Index Mundi, www.indexmundi.com

[11] NWASCO, 2014,'Urban and Peri-Urban Water Supply and Sanitation Sector Report 2014’’, pp 2

[12] Africa-EU Energy Partnership (2013). Zambia Power Sector Market Brief: Zambia. http://www.ruralelec.org/fileadmin/DATA/Documents/06_Publications/Market_intelligence/AEEP_Zam bia_Power_Sector_Market_Brief_EN.pdf

[13] Ministry of Mines, Energy and Water Development of Zambia[MEWD] (2008). National Energy Policy. http://www.mewd.gov.zm/

[14] ZESCO (2013b) , 'Electricity Infrastructure Development for Economic Growth', North CPD presentation. pg12

[15] http://www.zesco.co.zm

[16] J.Mahere, 2010, Integration of Facts Devices in the Zesco Power System to Improve Power Transfer Capability and Stability, Thesis for the MEng in Electrical Power Systems, Kathmandu University, Kathmandu, Nepal.

[17] Energy Regulation Board (ERB), 2010b, 'SState of Infrastructure report', Lusaka.

[18] Mabvuto Mwanza, Navaraj Karki, Nabina Pradhan, 2012,'Zesco Generation System Adequacy Assessment for the Period 2009-2030 using Probabilistic Approach', DOI:10.2316/P.2012.760-036, IASTED 2012 African Conference-2012.

[19] H.Walimwipi, Snow Systems Zambia, 2012,'’Investment Incentives for Renewable Energy in Southern Afirca: Case Study of Zambia', International Institute for Sustainable Development (IISD) December 2012.

[20] Department of Energy (DoE), 2010, 'Draft Renewable Energy Strategy for Zambia', Department of Energy.

[21] Yan-wei Sun, Angela Hof, Run Wang, Jian Liu, Yan-jie Lin, De-wei Yang, 2013“'GIS-based approach for potential analysis of solar PV generation at the regional scale: A case study of Fujian Province" Energy Policy 58 (2013) 248-259, ScienceDirect. 
[22] United Nations Industrial Development Organization, 2009, 'UNIDO and Renewable Energy; Greening the Industrial Agenda' Vienna, 2009.

[23] Kasanga Chiwama, et al ,2012, 'Feasibility Study of Domestic Biogas Programme in Zambia' SNV and Hivos Private Dutch Development Agencies.

[24] REA(Rural Energy Agency),2008,'Pre-feasibility Study Chilinga Hydro, Memo 2008-078, ECON-ESD pp.39

[25] Mwansa Kaoma, Shadreck Mpanga, Mabvuto Mwanza, Mundia Muya, Donat Ngendo, Ackim Zulu, et al, 2015,'State of Renewavble Energy Technologies in Southern African' International Conference on Clean Energy for Sustainable Growth in Developing Countries, September 16-18 2015, Palapye, Botswana

[26] Anthony Lopez, Billy Roberts, Donna heimiller, Nate Blair, Gian Porro, 2012,'’U.S Renewable Energy Technical Potentials: A GIS-Based Analysis"' Technical Report NREL/TP-6A20-5146, July 2012.

[27] Ottmar Edenhofer, Ramon Pichs-Madruga, Youba Sokona, 2012'"Renewable Energy Sources and Climate Change Mitigation: Summary for Policymakers and Technical Summary'. Special report of the Intergovernmental Panel on Climate Change IPCC, 2011, Intergovernmental Panel on Climate Change, ISBN 978-92-9169-131-9.

[28] DOE Office of Energy Efficiency and Renewable Energy (EERE). (October 2006 updated January 2011).' 'Report to Congress on Renewable Energy Resource Assessment Information for the United States." January 2011 (EPACT) Prepared by the National Renewable Energy Laboratory.

[29] Doug Dahle, Dennis Elliott, Donna Heimiller, Mark Mehos, Robi Robichaud, Marc Schwartz, et al, 2008," Assessing the Potential for Renewable Energy Development on DOE Legacy Management Lands'. NREL, DOE/GO-102 008-2435, February 2008

[30] Pourian Alamdari, Omid Nematollahi, Ali Akbar Alemrajabi, 2013,' Solar energy potentials in Iran: A review' Renewable and sustainable energy reviews 21 (2013) 778-788, ScienceDirect.

[31] Serhat Sensoy, Yusuf Ulupinar, Mesut Demircan, Ilker Alan, Zuhal Akyurek, Pinar A.Bostan, 2010, 'Modeling Solar Energy Potential in Turkey'.

[32] Rodrigo A. Escobar,Alberto Ortega, Cristian Cortes, Alan Pinot, Enio Bueno Pereira, Fernando Ramos Martins, et al, 2014' Solar Energy Resource Assessment in Chile: Satellite estimation and ground station measurement', Energy Procedia 57 (2014) 1257-1265, ScienceDirect.

[33] Anwar Mustefa Mahmud, Mulu Bayray Kahsay, Asfafaw Hailesilasie, Ftwi Yohanness Hagos, Petros Gebray, Hailay Kiros Kelele, et al, 2014', Solar Energy Resource Assessment of the Geba Catchment, Northern Ethiopia', Energy Procedia 57 (2014) 1266-1274, ScienceDirect.

[34] http://www.alibaba.com/product-detail/High-efficiency-good-price-pv solar 1824340428.html?spm=a2700.7724838.30.26.KvgWT1\&s=p 